\title{
Therapeutic Potency of Mangosteen (Garcinia Mangostana) Peel Extract for Shigella Dysenteriae Infected Mice's Colon Mucosal Destruction
}

\author{
Achmad Ilham Rizwani ${ }^{1}$, Arifa Mustika ${ }^{2 *}$, Lindawati Alimsardjono ${ }^{3}$, Tri Hartini Yuliawati ${ }^{4}$, Priyo \\ Budi Purwono ${ }^{3}$
}

\footnotetext{
${ }^{1}$ Faculty of Medicine, Universitas Airlangga, Surabaya.

2 Department of Pharmacology and Therapy, Faculty of Medicine, Universitas Airlangga, Surabaya.

${ }^{3}$ Department of Microbiology, Faculty of Medicine, Universitas Airlangga, Surabaya.

${ }^{4}$ Department of Anatomy and Histology, Faculty of Medicine, Universitas Airlangga, Surabaya.
}

\section{A B S T R A C T}

Introduction: Antibiotics treatment for bacillary dysentery due to Shigella dysenteriae infection have shown resistance. Mangosteen (Garcinia maangostana) peel had a therapeutic potency for Shigella dysenteriae infection due to its antibacterial and anti-inflammatory activity.

Methods: The research was experimental, 30 mice were used which was divided into 5 groups. The mice were infected with Shigella dysenteriae intraperitoneally, then azithromycin, aquadest, and 3 different doses of mangosteen (Garcinia mangostana) peel were given for each group for 5 days, which then the mice's colon were collected and made into histology specimen and its mucosal destruction was observed in three fields of view in each specimen, 1 - 4 score was given according to its mucosal destruction. Kruskal-Wallis test was used to analyze the data and then Mann Whitney test also used for further analysis.

Results: There was colon mucosal improvement observed when mangosteen (Garcinia mangostana) peel extract was given, $100 \mathrm{mg} / \mathrm{Kg}$ body mass dose of mangosteen (Garcinia mangostana) peel extract already given a positive effect on mice's mucosal colon histology appearance, no difference observed between the 3 doses given.

Conclusion: Mangosteen (Garcinia mangostana) peel extract gave appearance improvement to the colon mucosal wall of mice with Shigella dysenteriae infection at the dose of $100 \mathrm{mg} / \mathrm{Kg}$ body mass.

\footnotetext{
* Correspondence: arifa-m@fk.unair.ac.id

JUXTA: Jurnal IImiah Mahasiswa Kedokteran Universitas Airlangga p-ISSN: 1907-3623; e-ISSN: 2684-9453

DOI: 10.20473/juxta.V10I12019.5-10

Open access under Creative Commons Attribution-ShareAlike 4.0 International License (CC-BY-SA) (c) (i) (2)
}

ARTICLE INFO

Article history:

Received 03 December 2018

Received in revised form 22 January 2019

Accepted 24 January 2019

\section{Keywords:}

Mangosteen peel extract, Shigella dysenteriae, bacillary dysentery, Mice's colon mucosal. 


\section{Introduction}

Shigella dysenteriae, one of four Shigella species that cause bacillary dysentery, a type of a diarrhea followed by mucus and bleeding along with the feces ${ }^{1}$. Shigella species has shown resistance to Sulfonamides, Tetracycline, Ampicillin, and Trimethoprim-Sulfomethoxazole, these antibacterial drugs were no longer recommended ${ }^{2}$. Due to the emergence of the antibacterial resistance, the drug of choice of this particular infection narrowed to Ceftriaxone, Ciprofloxacin, Ofloxacin, and Azithromycin ${ }^{3}$. Despite the regiment of the drug of choice being narrowed, Shigella species still showing resistance to Azithromycin and Floroquinolone ${ }^{4}$. Shigella species have shown a decrease in susceptibility to Azithromycin ${ }^{5}$ and Azithromycin resistance is a problem emerging in South-east Asia ${ }^{6}$.

The infection occurs worldwide and at all ages, but under 5-year-old children in low or middle-income countries had the highest burden to this infection and it cause 164.000 death annually ${ }^{7}$. In Indonesia, the burden of this infection has shown emergence ${ }^{8}$ and in South Jakarta, it happens in 32 per 1000 infants age 1-2 years old ${ }^{9}$.

At the other side, Mangosteen (Garcinia mangostana) peel extract has shown antibacterial potency to Shigella dysenteriae in an in vitro experiment with Minimum Bactericidal Concentration (MBC) at $12.5 \%$ extract concentration $^{10}$. Dried powder and fresh extract of Mangosteen (Garcinia mangostana) both showed antibacterial property but the fresh extract showed better efficacy in antibacterial activity ${ }^{11}$. The combination between Mangosteen (Garcinia mangostana) peel and pericarp extract also showed a bactericidal property to Shigella dysenteriae ${ }^{12}$

The antibacterial activity of Mangosteen (Garcinia mangostana) peel extract happens due to its active substance such as alkaloid, saponin, triterpenoid, tannin, flavonoid, glycoside, and polifenol ${ }^{13}$. The inflammation occurred in the colon mucosal wall can also be healed due to its two types of xanthones, $\alpha$ - and $\gamma$-mangosteens, its anti-inflammatory effect will reduce the level of COX-2, IL6 , IL-1 $\beta$, and Nitric Oxide ${ }^{14,15}$. These two properties of Mangosteen (Garcinia mangostana) peel extract shows a promise in improving the colon mucosal condition after its destruction due to Shigella dysenteriae.

This study aims to discover the Mangosteen (Garcinia mangostana) peel extract therapeutic effect to the destruction of colon mucosal wall in mice model (In vivo study) and the difference with one drug of choice, Azithromycin.

\section{Methods \\ Material}

The study uses Mangosteen (Garcinia mangostana) peel extract from Balai Materia Medica, Malang. Shigella dysenteriae obtained from Microbiology laboratory, Department of Microbiology, Faculty of Medicine, Universitas Airlangga. The study also used30 BALB/c mice (Mus musculus)age 8-12 weeks with $25-30 \mathrm{mg}$ body weight and Azithromycin obtainedfrom Pharmacology laboratory,
Department Pharmacology and Therapy, Faculty of Medicine Universitas Airlangga. Optical microscope and Olympus CellSens application were also used to evaluate the colon mucosal wall in this study.

\section{Material Preparation}

Mangosteen extracted with maceration methods and $96 \%$ alcohol used as solvent, then mangosteen (Garcinia mangostana) peel extract made into suspension with main dose/medium dose of $200 \mathrm{mg} / \mathrm{Kg}$ Body Mass, half of the main dose/low dose (100 mg/Kg Body Mass), and twice of the main dose/high dose $(400 \mathrm{mg} / \mathrm{Kg} \text { Body Mass })^{16-18}$. With the average weight of the mice was 25 gram, the low dose group received 4 gram of extract, the medium dose group received 8 gram of extract, and the high dose group will receive 16 gram of extract.

The dose of Azithromycin used in the experiment adjusted from the humanto mice dose conversion, according to its body surface and weigh $6 \mathrm{mg}$ of Azithromycin was used for this experiment ${ }^{19,20}$

The mice were placed at the separated cage 7 days before the experiment, allowing the mice to adapt to its new environment.

\section{Experimental Procedure}

The mice is first infected with Shigella dysenteriae, 1 $\mathrm{ml}$ suspension of 4 McFarland Shigella dysenteriae injected to the mice intraperitoneally ${ }^{21,22}$. The mice is incubated for 2 days ${ }^{23}$. After the incubation period, a mouse terminated with ether and the proximal colon collected to determine if the infection were succesfull ${ }^{23}$.

After the incubation was done, 30 mice are divided into five groups, each group were divided into the following group.

- Positive control group administered with $6 \mathrm{mg}$ Azithromycin + CMC Na $1 \%$ in $0.3 \mathrm{ml}$ aquadest,

- The negative control group received $0.3 \mathrm{ml}$ aquadest.

- The first group administered with 4 gram mangosteen (Garcinia mangostana) extract + CMC Na $1 \%$ in $0.3 \mathrm{ml}$ aquadest.

- The Second group administered with 8 gram mangosteen (Garcinia mangostana) extract + $\mathrm{CMC} \mathrm{Na}$ $1 \%$ in $0.3 \mathrm{ml}$ aquadest.

- The Second group administered with 16 gram mangosteen (Garcinia mangostana) extract + CMC Na $1 \%$ in $0.3 \mathrm{ml}$ aquadest.

Each group received the treatment orally once every 24 hours, at 10 AM daily for 5 days. After the treatment was done, the mice is terminated with ether and the proximal colons were collocted ${ }^{23}$. The colon collected were made into a histology specimen with HE staining. The destruction observed in three fields of view per specimen and score of 1-4 were given according to its mucosal destruction.

\section{Mucosal Destruction Scoring}


The mucosal destruction is evaluated by the infiltration of Poli-Morpho-Nuclear (PMN) inflammatory cells and the mucosal architructure ${ }^{24}$. The higher score was given to the most destructed colon mucosal wall and vice versa. The scoring used in this experiment is illustrated in table 1 and figure 1.

Table 1Scoring System in the Research

\begin{tabular}{cl}
\hline Score & Description \\
\hline 1 & $\begin{array}{l}\text { No mucosal architecture destruction and PMN } \\
\text { infiltration in the mucosal level. }\end{array}$ \\
2 & $\begin{array}{l}\text { No mucosal architecture destruction and PMN } \\
\text { infiltration in the mucosal and submucosal } \\
\text { level. }\end{array}$ \\
3 & $\begin{array}{l}\text { No mucosal architecture destruction and PMN } \\
\text { infiltration in the mucosal and diffuse infiltration } \\
\text { at the submucosal level. } \\
\text { Mucosal architecture destruction (Ulceration, } \\
\text { Granulation), PMN infiltration mucosal and } \\
\text { submucosal level. }\end{array}$ \\
\end{tabular}

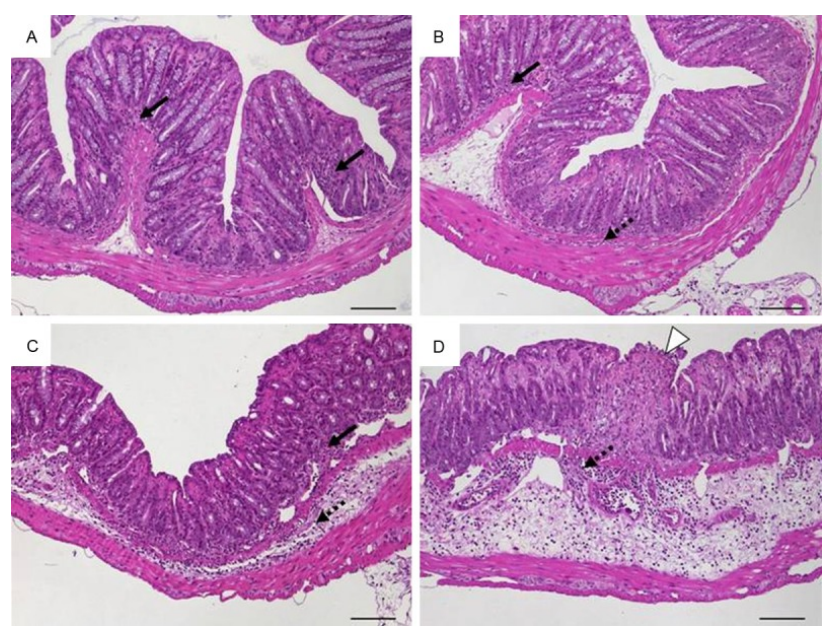

Figure 1 Scoring standardA. Score 1: intact epithelium and $\mathrm{PMN}$ cell infiltrate in the mucosa; $\mathrm{B}$. Score 2: scattered PMN in mucosa and submucosa; C. Score 3: diffuse mucosal and submucosal PMN infiltrates; D. Score 4: moderate PMN infiltrates in the submucosa with architectural destruction. Original magnification $\times 100 .{ }^{24}$

\section{Results \\ Infection Evaluation}

One mouse was terminated after the incubation period for 2 days. The proximal colon was collected and made into a histologic slide. Three fields of view observed and no architectural destruction (such as ulceration or granulation) identified, most of the field of view showed diffuse PMN infiltration at the submucosal and mucosal layer. Score 3 were given, evaluated from three fields of view of this histologic slide,
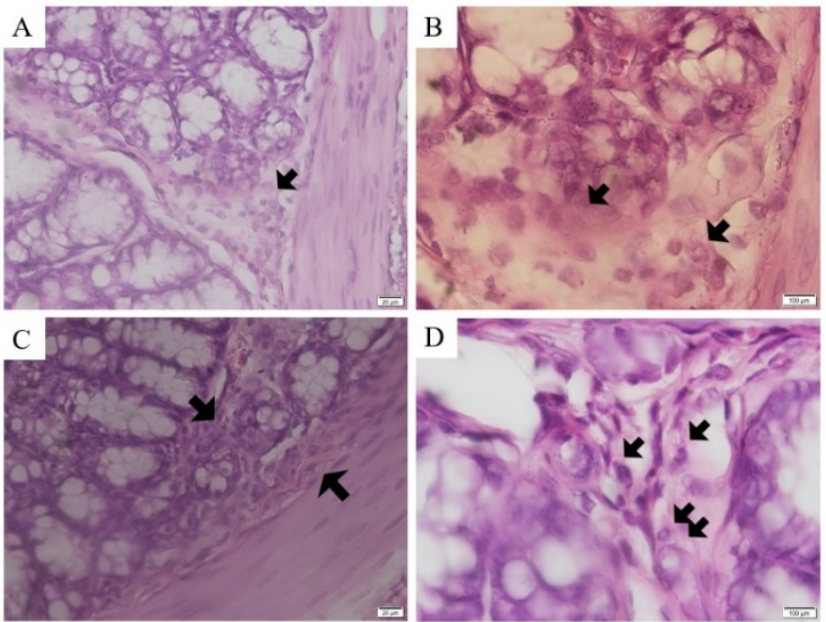

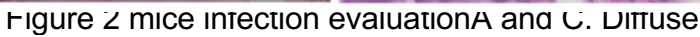
submucosal PMN infiltration (400x magnification); $B$.

Submucosal PMN infiltration (1000x magnification); D. Mucosal PMN infiltrates

\section{Scoring Adjustment}

After the treatment was done, the histology specimen was observed to adjust the scoring system. We were able to use the scoring system from Table 1, with these following evaluated structures.
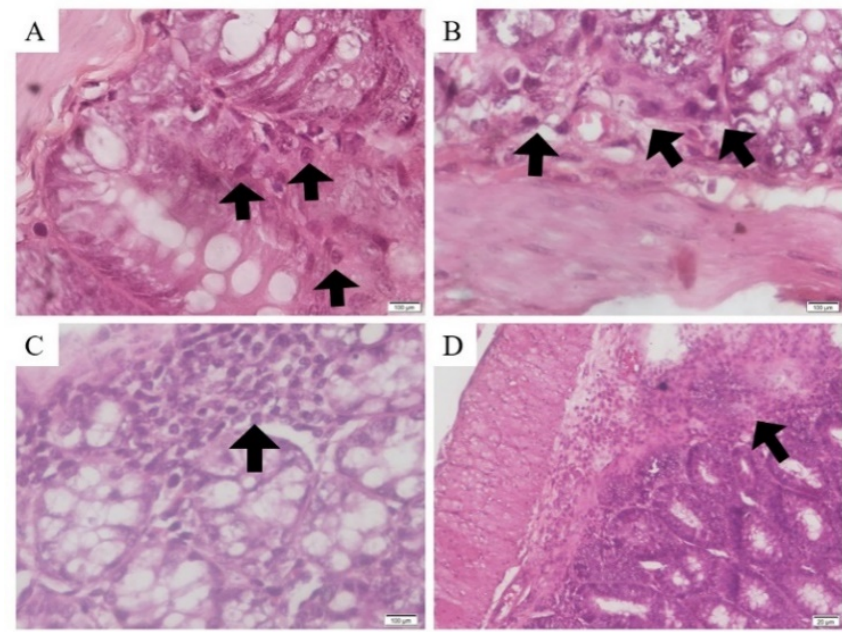

Figure 3 evaluated structureA. The mucosal wall with PMN infiltration (1000x magnification); B. Submucosa

layer with PMN infiltration (1000x magnification); C.

Diffuse PMN infiltration in mucosa and submucosa layer (1000x magnification) ; D. ulceration (100x Magnification).

\section{Colon Mucosal Histology Appearance Evaluation}

The positive control group showed the least destructed mucosal appearance with mucosal PMN infiltration only in most sample, although some group showed some higher score but the positive group dominated with score 1 appearance. On the other hand, the negative control group showed the most destructed mucosal appearance. Score 4 and 3 appearance were dominated this group.

The 3 groups administered with mangosteen (Garcinia mangostana) peel extract showed mucosal wall 
appearance of score 1 to score 3 with no sample identified as score 4 . Every groups were dominated by score 1 and score 2 appearance.
Mann whittney test were showing negative control groups were significantly different with the other groups $(P<0.05)$, Azithromycin groups were not significantly different with 3 doses of extract groups ( $P>0.05$ ), and among the 3 doses of extract given there were no significant difference observed $(P>0.05)$.

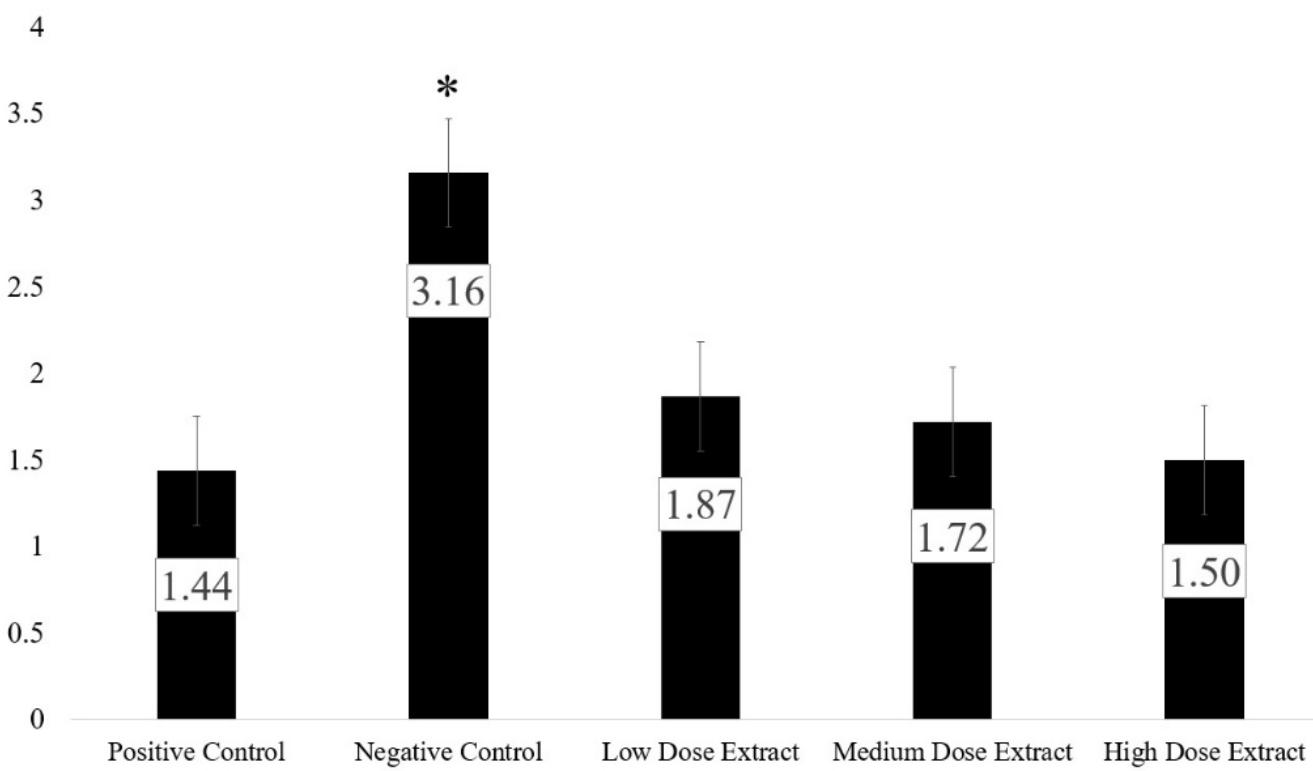

*) Significant difference with the other groups $(\mathrm{P}<0.05)$

Figure 4. Mean value from overall colon mucosal histologic appearance

\section{Discussion \\ Mice transmission of Shigella dysenteriae with intraperitoneal administration}

The mice were administered with Shigella dysenteriae intraperitoneally. From the trial mouse, Figure 2 were showing there were diffuse submucosal and mucosal infiltration of PMN inflammatory cells, which indicate moderate inflammation occurred in colon wall. The trial mouse showed the score of 3 in three fields of view, according to the scoring system used in this research the colon mucosal wall destruction happened after the intraperitoneal administration of Shigella dysenteriae.

Oral route transmission of Shigella dysenteriae were not able to infect the mice, the host-defense mechanism to Shigella dysenteriae either with host cell death or epithelial shedding mechanismwere not allowing the infection to occur at the colon mucosa of the mice ${ }^{25}$. The other route of administration possible to infect Shigella dysenteriae to the mice were intraperitoneal route because the bacteria which enter from the peritoneal cavity will escape the hostdefense mechanism ${ }^{21}$.

Kruskall-Wallis test shown, there were a relation between the treatment group (Azithromycin and 3 doses of extract) and the colon mucosal destruction with $P=0.011(P<0.05)$.
The severity of colon wall destruction occurred in the research were not similar with the human infection. Human infected with Shigella dysenteriae, were showing oedema and haemorrhage in colon histology appearance ${ }^{26}$, thus in mice's colon it only shows architecture destruction such as ulceration andgranulation. The intraperitoneal administration of Shigella dysenteriae to a mouse animal model were able to shows the sign of inflammatory process and mucosal wall architectural destruction. But the mice model was not showing the same human infection histology appearance.

\section{Non-Infected and Infected Mice Colon Histologic Appearance Comparison}

Mice from positive control group and the 3 doses of extract groups showed the closest appearance to a healthy mice colon histology compared to the negative control groups, with the histological score between 1 and 2 . According to the scoring system used in the research, score 1 gave the healthiest histology appearance and score 4 gave the appearance of severely destructed colon mucosal wall.

There were no architectural defects like ulceration and granulation in non-infected mice colon histologic appearance, it also showed normal infiltration of PMN in mucosal layer, few submucosal PMN infiltration were also 
a normal appearance in a non-infected mice, but it indicates more inflammation occured ${ }^{27}$.

Score 1 and 2 were an appearance close of noninfected mice,but score 1 was still the closest to a healthy colon appearance. Mice from positive control groups and the 3 doses of extract groups were showing average score between score 1 and 2, these groups indicated a close appearance to the non-infected mice colon histology.

\section{Therapeutic Effect of Mangosteen (Garcinia mangostana) peel extract to the colon mucosal wall of Shigella dysenteriae infecter mice model}

Mangosteen (Garcinia mangostana) peel extract improved the condition of mice's colon mucosal wall infected with Shigella dysenteriae. Extract of mangosteen (Garcinia mangostana) peel were not showing a significant difference with the regiment of Azithromycin. The similarity between the extract and the antibiotics treatment, indicated mangosteen (Garcinia mangostana) peel extraction ability to improve the appearance of colon mucosa histology.

Therapeutic effect of the extract based on two effects, first mangosteen (Garcinia mangostana) peel extract had an antibacterial activity to Shigella dysenteriae ${ }^{10-12}$. Mangosteen (Garcinia mangostana) peel extract also had the antibacterial properties for other bacteria, such as $L$. monocytogenes and $S$. aureus ${ }^{28}$. The antibacterial properties of the extract killed Shigella dysenteriae,the cause of colon mucosal wall destruction, thus the improvement of colon mucosal wall was able to be observed.

The second effect that causes the ability to improve the colon mucosal wall structure were the anti-inflammatory properties ${ }^{14},{ }^{15}$. The pro-inflammatory cytokines level reduced due to the effect and the inflammation process were stopped. Without further inflammatory process, the colonic mucosal wall destruction stopped since there was no host-defense mechanism to fight back Shigella dysenteriae. The anti-inflammatory process could trigger a masking effect, an effect in which colon mucosal wall seems not infected but the pathogen remained at the colon $^{29}$.

There was no significant difference among the three groups of the extract treatment. Thus, we conclude mangosteen (Garcinia mangostana) peel extract had the therapeutic effect to improve colon mucosal wall of Shigella dysenteriae infected mice animal model and the low dose of extract treatment, $100 \mathrm{mg} / \mathrm{Kg}$ Body mass already be able to improve mucosal wall appearance.

\section{The Comparison of Azithromycin and Mangosteen (Garcinia mangostana) Peel Extract}

As mention before, three doses of mangosteen (Garcinia mangostana) peel extract were not showing significant difference with Azithromycin treatment. The major difference between these two therapies was the anti- inflammatory property of mangosteen (Garcinia mangostana) peel extract and Azithromycin only had a strong antibacterial property. If the antibacterial properties of mangosteen (Garcinia mangostana) peel extract did not work, its anti-inflammatory properties of mangosteen (Garcinia mangostana) peel extract couldstill be improving the colon mucosal appearance. And this effect could lead to no significant difference between Azithromycin and mangosteen (Garcinia mangostana) peel extract treatment.

Azithromycin is a potent antibacterial agent, it stopped protein synthesis of bacteria in this case Shigella dysenteriae, without protein synthesis bacteria will eventually die and the termination of the pathogen will lead to a healing process by the body ${ }^{30}$. Thus, improved the histologic appearance of colon mucosal wall.

Azithromycin and mangosteen (Garcinia mangostana) peel extract showed no difference in term of improving the colon mucosal condition post-Shigella dysentery infection. But the anti-inflammatory properties of mangosteen (Garcinia mangostana) peel extract differs Azithromycin from mangosteen (Garcinia mangostana) peel extract treatment.

\section{Conclusion}

Mangosteen (Garcinia mangostana) peel extract treatment improved the colon mucosal wall of mice post Shigella dysenteriae infection, 100 mg extract per Kg Body mass already showed the improvement of mice's mucosal wall appearance. There was no difference between Azithromycin and mangosteen (Garcinia mangostana) peel extract treatment in term of improving the colon mucosal wall of mice post Shigella dysenteriae infection.

\section{CONFLICT OF INTEREST}

The author stated there is no conflict of interest.

\section{REFERENCES}

1. Levine MM. Bacillary Dysentery: Mechanisms and Treatment. Medical Clinics of North America. 1982; 66: 623-38.

2. Jaya Sureshbabu M, MRCPCH(UK), MRCPI(Paeds), MRCPS(Glasg), DCH(Glasg). Shigella Infection. Medscape. 2018.

3. Sk N. Niyogi SK: Shigellosis, J.Microbiol. 43(2):13343,2005. 2005.

4. Puzari M, Sharma $M$ and Chetia P. Emergence of Antibiotic Resistant Shigella Species: A Matter of Concern. Journal of Infection and Public Health. 2018; 11: 451-4.

5. Kenya M, Vasudha R, John K, et al. Increasing Antibiotic Resistance in <em $>$ Shigella $</$ em $>$ spp. from Infected New York City Residents, New York, USA. Emerging Infectious Disease Journal. 2017; 23: 332.

6. Darton TC, Tuyen HT, The HC, et al. Azithromycin Resistance in Shigella spp. in Southeast Asia. Antimicrobial Agents and Chemotherapy. 2018; 62: e01748-17.

7. Kotloff KL, Riddle MS, Platts-Mills JA, Pavlinac $P$ and Zaidi AKM. Shigellosis. Lancet (London, England). 2018; 391: 801-12. 
8. Subekti D, Oyofo BA, Tjaniadi $P$, et al. Shigella spp. Surveillance in Indonesia: The Emergence or Reemergence of S. dysenteriae. Emerging Infectious Diseases. 2001; 7: 137-40.

9. Agtini MD, Soeharno R, Lesmana M, et al. The Burden of Diarrhoea, Shigellosis, and Cholera in North Jakarta, Indonesia: Findings from 24 months Surveillance. BMC Infectious Diseases. 2005; 5: 89.

10. Parni Astuti HS. Aktivitas Antibakteri Ekstrak Etanol 96\% Kulit Buah Manggis (Garciniamangostana L.) terhadap Bakteri Shigella dysenteriae dan Bacillussubtilis Sebagai Materi Pelajaran Biologi SMA Kelas X untukMencapai Kompetensi Dasar 3.4 Kurikulum 2013. JUPEMASI-PBIO. 2014; 1: 46-52.

11. Mauliddiyah I. Kajian tentang Daya Antibakteri Ekstrak Kulit Buah Manggis (Garcinia mangostana L.) Bentuk Segar dan Kering dalam Beberapa Macam Konsentrasi terhadap Shigella dysentriae sebagai Materi Bahan Ajar Mikrobiologi. 2012.

12. Prasaja D, Darwis W and Astuti S. Uji Efektivitas Kombinasi Ekstrak Kulit Batangdan Kulit Buah Manggis (Garcinia mangostana L.) Sebagai Antibakteri Shigella dysentriae. Jurnal Ilmu Lingkungan; Vol 12, No 2 (2014): Oktober 2014. 2016.

13. Poeloengan M and Praptiwi P. Uji Aktivitas Antibakteri Ekstrak Kulit Buah Manggis (Garcinia mangostana Linn). 2012.

14. Widowati W, Darsono L, Suherman J, Fauziah N, Maesaroh M and Erawijantari PP. Anti-Inflammatory Effect of Mangosteen ( Garcinia mangostana L.) Peel Extract and Its Compounds in LPS-induced RAW264.7 Cells. 2016; 22: 147.

15. Chen LG, Yang LL and Wang CC. Anti-Inflammatory Activity of Mangostins from Garcinia mangostana. Food and Chemical Toxicology : An International Journal Published for the British Industrial Biological Research Association. 2008; 46: 688-93.

16. Muhartono M, Rivanda A, Janar Wulan A and Susianti S. Pengaruh Ekstrak Kulit Manggis (Garcinia mangostana L.) Terhadap Testis Tikus Putih yang Diberi Paparan Gelombang Elektromagnetik Handphone. 2017, p.144.

17. Adipratama IK, Tjahjono $\mathrm{K}$ and Setyawati AN. Pengaruh Pemberian Ekstrak Kulit Manggis (Garcinia mangostana) dan Simvastatin terhadap Kadar Kolesterol HDL Tikus Sprague - Dawleydengan Pakan Tinggi Lemak. Jurnal Kedokteran Diponegoro; Vol 3, No 1 (2014): Media Medika Muda.
18. Fidayani Pasaribu PS, Saiful Bahri. Uji Ekstrak Etanol Kulit Buah Manggis (Garcinia mangostana L.) terhadap Penurunan Kadar Glukosa Darah. Journal of Pharmaceutics and Pharmacology. 2012; 1.

19. Williams PCM and Berkley JA. Guidelines for the Treatment of Dysentery (shigellosis): A Systematic Review of the Evidence. Paediatrics and International Child Health. 2018; 38: S50-S65.

20. Nair AB and Jacob S. A Simple Practice Guide for Dose Conversion between Animals and Human. Journal of Basic and Clinical Pharmacy. 2016; 7: 27-31.

21. Yang JY, Lee SN, Chang SY, Ko HJ, Ryu S and Kweon MN. A Mouse Model of Shigellosis by Intraperitoneal Infection. The Journal of Infectious Diseases. 2014; 209: 203-15.

22. Sriagung Fitri Kusuma SRM, Indah Firdayani, Resmi Mustarichie. Studyonthe Antibacterial Activityof Fruit Extractsof Klutuk Banana (Musa Balbisiana Colla) against Shigella Dysenteriaeatcc 13313. 2017; 10.

23. Jawetz, Melnick, \& Adelberg's Medical Microbiology, Twenty-Sixth Edition. 26th ed.: The McGraw-Hill Companies, Inc, 2013.

24. Erben U, Loddenkemper C, Doerfel K, et al. A Guide to Histomorphological Evaluation of Intestinal Inflammation in Mouse Models. International Journal of Clinical and Experimental Pathology. 2014; 7: 4557-76.

25. Chang SY, Lee SN, Yang JY, et al. Autophagy Controls an Intrinsic Host Defense to Bacteria by Promoting Epithelial Cell Survival: A Murine Model. PloS one. 2013; 8: e81095.

26. Vinay Kumar M, MD, FRCPath, Abul K. Abbas, MBBS and Jon C. Aster, MD, PhD. Robbins \& Cotran Pathologic Basis of Disease, 9th Edition. Elsevier, 2015.

27. Wang JNRaJ-Y. Regulation of Gastrointestinal Mucosal Growth. San Rafael (CA): Morgan \& Claypool Life Sciences, 2010.

28. Palakawong C, 1, Sophanodora P, 2, Pisuchpen Sa and Phongpaichit S. Antioxidant and Antimicrobial Activities of Crude Extracts from Mangosteen (Garcinia mangostana L.) Parts and Some Essential Oils. International Food Research Journal. 2010; 17: 583-9.

29. Side-Effects of Anti-Inflammatory Drugs 3. 1 ed.: Springer Netherlands, 1992, p.XX, 376.

30. Trevor A KB, Kruediring M. Katzung \& Trevor's Pharmacology: Examination \& Board Review. . 11th ed. Philadelpia: PA.: McGraw-Hill, 2015. 